\title{
Review
}

\section{The role of Vitamin D in malaria}

\author{
Khanh Vinh Quốc Lương, Lan Thi Hoàng Nguyễn \\ Vietnamese American Medical Research Foundation, Westminster, California, United States
}

\begin{abstract}
An abnormal calcium-parathyroid hormone (PTH)-vitamin D axis has been reported in patients with malaria infection. A role for vitamin D in malaria has been suggested by many studies. Genetic studies have identified numerous factors that link vitamin D to malaria, including human leukocyte antigen genes, toll-like receptors, heme oxygenase-1, angiopoietin-2, cytotoxic T lymphocyte antigen-4, nucleotide-binding oligomerization domain-like receptors, and Bcl-2. Vitamin D has also been implicated in malaria via its effects on the Bacillus CalmetteGuerin (BCG) vaccine, matrix metalloproteinases, mitogen-activated protein kinase pathways, prostaglandins, reactive oxidative species, and nitric oxide synthase.

Vitamin D may be important in malaria; therefore, additional research on its role in malaria is needed.
\end{abstract}

Key words: vitamin D; malaria; calcitriol.

J Infect Dev Ctries 2015; 9(1):008-019. doi:10.3855/jidc.3687

(Received 17 April 2013 - Accepted 01 October 2013)

Copyright (C) 2015 Luong et al. This is an open-access article distributed under the Creative Commons Attribution License, which permits unrestricted use, distribution, and reproduction in any medium, provided the original work is properly cited.

\section{Introduction}

Parathyroid hormone (PTH) regulates the levels of calcium and phosphate in the blood by modulating the activity of specific cells in bones and kidneys. PTH stimulates the release of calcium and phosphate from bone and the reabsorption of calcium; it also inhibits reabsorption of phosphate from glomerular filtrate of the kidneys, and stimulates renal synthesis of 1,25dihydroxyvitamin $\mathrm{D}_{3}$ (calcitriol), thereby increasing intestinal absorption of calcium and phosphate [1]. An abnormal calcium-PTH-vitamin D axis has been reported in patients with malaria infections. Parathyroid gland dysfunction is a cause of hypocalcemia in severe malaria without acute renal failure [2]. Hypocalcemia is not uncommon in complicated malaria. Mean calcium levels are significantly lower in complicated malaria when compared to uncomplicated malaria. Hypocalcemia can be of prognostic value, as it may indicate complicated malaria or heavy parasitemia, and its return to normal may indicate clinical recovery and parasite clearance [3]. In acute falciparum malaria, mild hypocalcemia is common and simultaneously associated with inappropriately low serum PTH [4]. A role for vitamin $\mathrm{D}$ in malaria has been suggested by many studies. The death rate in mice infected with Plasmodium berghei was improved with the addition of cod liver oil or vitamin D and dicalcium phosphate to quinine [5]. High levels of vitamin D reduced the capacity of $P$. berghei to penetrate the erythrocyte membrane [6]. Moreover, vitamin $D$ and its derivatives inhibited intra-eryhrocytic growth of $P$. faciparium in vitro [7]. Ray et al. [8] found an increased expression of vitamin D receptor (VDR) in $P$. vivax malaria patients. They suggested some association between VDR polymorphism and disease severity of malaria. These findings suggest that there is a relationship between vitamin $\mathrm{D}$ and malaria. Therefore, in the present paper, we reviewed the role of vitamin $\mathrm{D}$ in malaria.

\section{The genomic factors associated with vitamin $D$ in malaria}

Studies have suggested that human leukocyte antigen (HLA) genes are part of the major histocompatibility complex (MHC) class II. The HLA class II controls the immune response to p126-derived amino terminal peptide from $P$. falciparum [9]. The presence of HLA-DRB1 is associated with severe malaria [10-12] and is related to the high frequency of the IgG antibody response to the $P$. vivax circumsporozoite protein (CSP) and merozoite surface protein (MSP) [13-15]. The HLA-DQA alleles are associated with patients co-infected with circumsporozoite variants of $P$. falciparum in western Thailand [16], and the HLA-DQ1*0502 allele is 
associated with malaria in the Muong population in Vietnam [17]. However, DQB $1 * 0501$ restricted the Th1 type immune response to the $P$. falciparum liver stage antigen 1 and protected patients from malaria anemia and malarial re-infection in Gabonese children [18]. Moreover, calcitriol is known to stimulate phagocytosis, but it suppresses MHC class II antigen expression in human mononuclear phagocytes [19-20]. Calcitriol also decreases interferon-gamma-induced HLA-DR antigen expression in normal and transformed human keratinocytes [21-22]. Calcitriol inhibits differentiation, maturation, activation, and survival of dendritic cells and down-regulates MHC class II expression [23-24]. Calcitriol and its analogs modulate human dendritic cells by inhibiting HLA-DR expression [25]. Vitamin D analog ZK203278 potently inhibits lymphocyte proliferation in the mixed lymphocyte reaction and down-regulates MHC class II expression by $70 \%$ [26]. In addition, $1 \alpha$-calcidol significantly modulates the expression of HLA-DR in human peripheral blood monocytes [27]. Intrinsic 25OHD activation inhibited human dendritic cell antigen presentation and chemotaxis and reduced HLA-DR expression [28]. Calcitriol also improved graft survival in renal allografts by reducing macrophage infiltration and renal HLA-DR expression [29]. These findings suggest that calcitriol may have an effect on malaria through its suppression of the expression of MHC class II antigens.

Toll-like receptors (TLRs) are a group of glycoproteins that function as surface trans-membrane receptors and are involved in the innate immune response to exogenous pathogenic micro-organisms. $P$. falciparum primes human TLR responses toward a higher cytokine profile both in vitro and in vivo [30]. Patients with severe and mild malaria showed increased surface expression of TLR-2 and TLR-4 on $\mathrm{CD}^{+}$monocytes and myeloid dendritic cells [31]. Pre-incubation of peripheral blood mononuclear cells with $P$. falciparum-infected red blood cells enhances responsiveness to TLR ligands [32]. Malaria hemozoin is immunologically inert but radically enhances innate responses by activating TLR-9 [33-34]. Therapy with a synthetic antagonist of nucleic acid-sensing TLRs (E6446) diminishes the activation of human and mouse TLR-9 and prevents the exacerbated cytokine response observed during acute Plasmodium infection [35]. TLR-1 variants are involved in the recognition of $P$. falciparum and are both susceptible to and a manifestation of malaria in pregnancy [36]. TLR-4 polymorphisms are predisposed to severe malaria [37]. TLR-9 polymorphisms are susceptible to malaria in
Burundian children but are not related to malaria severity [38]. TLR-4 and TLR-9 polymorphisms play a role in the manifestation of malaria during pregnancy by increasing the risk of low birth weight in term infants and the risk of maternal anemia [39]. There are similar frequencies of TLR-2, TLR-4, and TLR-9 polymorphisms in malaria-endemic populations with different histories of malaria exposure [40]. Moreover, vitamin $\mathrm{D}$ deficiency increases the expression of the hepatic mRNA levels of TLR-2, TLR-4, and TLR-9 in obese rats [41]. However, calcitriol suppresses the expression of TLR-2 and TLR-4 mRNA and protein in human monocytes and triggers hypo-responsiveness to pathogen-associated molecular patterns [42]. Calcitriol has also been shown to down-regulate the intracellular expression of TLR-2, TLR-4, and TLR-9 in human monocytes [33]. Interestingly, TLR activation results in the expression of the VDR and $1 \alpha$-vitamin D hydroxylase in human monocytes [44].

Heme oxygenase-1 (HO-1) is a stress protein that may confer cytoprotection by enhancing the catabolism of pro-oxidant hemes into the radicalscavenging bile pigments biliverdin and bilirubin [45]. The HO-1 gene can be up-regulated by a host of noxious stimuli and is induced in the CNS tissues that are affected by neurological diseases [46]. In the normal brain, basal HO-1 expression is low and restricted to small groups of scattered neurons and neuroglia [47]. Infection with Plasmodium species resulted in the up-regulation of the host HO-1 [48]. HO-1 is expressed in activated monocytes and microglia in human cerebral malaria lesions [49]. The induction of HO-1 was demonstrated in tissue macrophages and monocytes in fatal malaria and sepsis [50]. The HO-1 expression is up-regulated in the liver following infection by $P$. berghei and $P$. yoelii sporozoites [51]. HO-1 polymorphism is associated with susceptibility to malaria [51-53]. A genetic predisposition to higher levels of $\mathrm{HO}-1$ is associated with severe malaria in Gambian children [54]. Moreover, vitamin D deficiency increases the expression of the hepatic mRNA levels of HO-1 in obese rats [41]. Calcitriol delays HO-1 immunoreactivity at the post-lesion survival time of 12 hours, and this delay is concomitant with a reduction in the glial fibrillary acidic protein immuno-reactivity in the remote cortical regions that are affected by the secondary spread of injury in the glial cells of the focal cerebral ischemic [55]; this supports the protective role of calcitriol in post-cellular injury.

Endothelial cell activation and dysfunction have been implicated in the pathogenesis of malaria, in 
which the endothelium responds to parasite-induced inflammation and mediates parasitized erythrocyte sequestration, especially in vital organs such as the brain [56]. Angiopoietins (Angs), a recently described distinct family of angiogenic proteins, have recently been shown to play fundamental physiological roles in maintenance of vascular integrity. Plasma levels of Ang-2 and ratio of Ang-2/Ang-1 are clinical biomarkers that can predict fatal cerebral malaria [5759]. Dysregulation of Angs is associated with placental malaria and low birth weight [60]. The association of increased Ang-2 and decreased nitric oxide are poor outcomes in severe P. falciparum [61$62]$. However, calcitriol inhibited the growth of tumorderived endothelial cells (TDECs) in two tumor models at nanomolar concentrations. The vitamin D analogs Ro-25-6760, EB1089, and ILX23-7553 were also potent inhibitors of TDEC proliferation. In squamous cell carcinoma and radiation-induced fibrosarcoma-1 cells, calcitriol treatment caused a reduction in the angiogenic signaling molecule angiopoietin-2 [63]. In addition, the vitamin $\mathrm{D}_{3^{-}}$ binding protein (Gc protein)-derived macrophage activating factor inhibited the endothelial cell proliferation, chemotaxis, and tube formation that were all stimulated by fibroblast growth factor-2, vascular endothelial growth factor-A, or Ang-2 [64]. Taken together, vitamin $\mathrm{D}$ may have a role in malaria by reducing Ang- 2 .

The phenotypes of $\mathrm{CD}^{+} \mathrm{T}$ cells are divided into Th1 and Th2 cells, which secrete predominantly interferon-gamma (IFN-r) and IL-4 [65], and another $\mathrm{CD}^{+}$phenotype, which uses the cytotoxic $\mathrm{T}$ lymphocyte antigen-4 (CTLA-4). CTLA-4 is involved in the regulation of $\mathrm{T}$-cells and is up-regulated during the T-cell-mediated immune response. CTLA-4positive cells are elevated in acute $P$. falciparum and vivax malarias in humans [66-68]. Murine malaria is exacerbated by a CTLA- 4 blockade, which induces higher parasitemia than in controls [69-71]. These findings suggest that CTLA-4 expression restricts pathogen-specific T-cell responses in malaria. Furthermore, Todryk et al. [72] demonstrated a deficiency in immune memory or regulatory activity in an experimental malaria challenge. The authors found that infected RBC-specific central memory responses, as measured by INF- $\gamma$, are low and unstable over time, despite the high proliferation of $\mathrm{CD}^{+} \mathrm{T}$ cells, and exhibit an inverse relationship to parasite density. Moreover, calcitriol promotes regulatory $\mathrm{T}$-cell profiles by increasing CTLA-4 and interleukin-10 in mouse colon protein extracts [73]. Calcitriol also stimulates the expression of high levels of CTLA-4 in human $\mathrm{CD}^{+} \mathrm{CD} 25^{-} \mathrm{T}$-cells [74]. In addition, vitamin $\mathrm{D}$ is required for interferon-gamma (IFN- $\gamma$ )-mediated antimicrobial activity of human macrophages [75].

The innate immune system is responsible for nonspecific defense against pathogens; stimulation of this system triggers the release of cytokines and chemokines. Nucleotide-binding oligomerization domain-like receptors are a diverse set of 22 innate immune receptors that are involved in the cytoplasmic detection of bacteria and the activation of inflammatory cascades [76-77]. The nucleotidebinding oligomerization domain containing 2 (NOD2) proteins detect the cell wall building block muramyl dipeptide and play a role in the immune response to many pathogens [78]. NOD2 stimulation has been shown to augment both Th1- and Th2-dependent responses [79-80]. Mice lacking NOD proteins show increased susceptibility to and impaired clearance of bacteria [81-82]. NOD proteins are up-regulated when PBMCs are exposed to malaria sporozoites [83], but these proteins have no direct effect on the survival or parasitemia of infected C57BL/6 mice. However, IL$1 \beta$ levels are associated with the activation of NODlike receptors and malaria pathogenesis. Reduced IL$1 \beta$ levels are observed in NOD mice during infection [84]. Malarial hemozoin-induced IL-1 $\beta$ and inflammation are dependent on a NOD-like receptor [85]. IL-1 $\beta$ has been implicated in the pathogenesis of human cerebral malaria and severe malaria anemia [86-87]. However, calcitriol strongly stimulates NOD2 expression in differentiated human THP-1 macrophage-like cells, primary human monocytes and keratinocytes [88], and boosts autophagy by enhancing NOD2 function [89]. The calcitriol-stimulated NOD2 function may contribute to host resistance to a variety of infectious challenges. In addition, many studies have found that calcitriol and VDR regulate cytokine responses and modulate IL-1 $\beta$ expression [90-92].

The proteins of the Bcl-2 family are key regulators of the apoptosis mitochondrial pathway [93]. These proteins control the permeability of the mitochondrial outer membrane, which releases cytochrome $\mathrm{C}$ and other apoptotic factors into the cytosol [94]. The mitochondrial apoptotic pathway plays a critical role in cell death during malarial infection. Kumar and Babu demonstrated extensive vacuolation and swelling of mitochondria associated with a high $\mathrm{Bax} / \mathrm{Bcl}_{2}$ ratio in mouse brains during experimental fatal murine cerebral malaria [95]. Down-regulation of Bcl-2 was observed in dying liver cells during malarial infection [96] and in placental malaria [97]. 
Glycosylphosphatidylinositol (GPI) purified from $P$. falciparum has been shown to play an important role as a toxin in the pathology of malaria. GPI-treated cardiomyocytes exhibit a down-regulation of the Bcl-2 gene [98]. Moreover, calcitriol inhibits hepatocyte apoptosis in rat allografts by regulating apoptosisassociated genes and increasing Bcl-2 levels [99]. Calcitriol stimulates endothelial cell proliferation, inhibited apoptosis, and increased Bcl-2 expression in apolipoprotein E-deficient mice [100]. Calcitriol also decreases Adriamycin-induced podocyte apoptosis and significantly increases $\mathrm{Bcl}-2$ expression [101]. Although it has been suggested that calcitriol stimulates endothelial cell proliferation and increases Bcl-2 expression, it is not clear whether this could affect the down regulation of the Bcl-2 gene due to $P$. falciparum GPI. However, calcitriol can induce human U937 promonocytic cells to express the CD14 gene and CD14 protein and can enhance the response of this type of cell to LPS stimulation [102]. CD14 was first described as a differentiation antigen on the surface of myeloid lineage cells. It acts as a GPI-anchored receptor for the complex of LPS and plays a key role in the activation of LPS-induced monocytes. Taken together, vitamin $\mathrm{D}$ may have a role in malaria via the increasing of apoptotic factor Bcl-2 expression.

\section{The non-genomic role of vitamin $D$ in malaria}

The Bacillus Calmette-Guerin (BCG) vaccine may protect against malaria via calcitriol production. Although the BCG vaccine was developed to provide protection against tuberculosis, BCG vaccination may affect the response to several major infections, including malaria. BCG was reported to protect mice against Babesia and Plasmodium [103]. BCG enhances the host immune response to $P$. berghei during an initial infection but shortens the length of immunity so that mice are more susceptible to $P$. berghei during subsequent infections [104]. The intravenous administration of BCG induces the greatest degree of suppression of sporozoite immunity in rodent malaria compared to intra-peritoneal and subcutaneous routes [105]. Having a BCG scar was found to significantly reduce the risk of death from malaria in children in Guinea-Bissau [106]. BCG has excellent adjuvant activity and has been used as a vector to deliver heterologous vaccine candidate antigens [107]. A recombinant BCG vaccine expressing circumsporozoit protein, merozoite surface protein-1, or $22 \mathrm{kDa}$ of serine repeat antigen of Plasmodium species, has been shown to function as a malaria vaccine [104-110]. These vaccines were demonstrated to enhance humoral and cellular immune responses, activate the inflammatory action of macrophages, and increase IFN- $\gamma$-producing cells. Furthermore, BCG-vaccinated infants are almost six times as likely to have sufficient vitamin D concentrations three months after receiving the BCG vaccine compared with unvaccinated infants, and this association remains strong even after adjusting for season, ethnic group, and sex [111]. In the vaccinated group, there is also a strong inverse correlation between the IFN- $\gamma$ response to $M$. tuberculosis PPD and vitamin $\mathrm{D}$ concentration (i.e., infants with higher vitamin $\mathrm{D}$ concentrations have lower IFN- $\gamma$ responses). Similarly, tuberculosis in cattle is typically associated with a rapid transient increase in serum calcitriol within the first two weeks of infection [112]. Calcitriol-positive mononuclear cells were later identified in all of the tuberculosis granulomas. During tuberculosis infection, the calcitriol produced by alveolar macrophages plays a beneficial role by limiting inflammation-mediated tissue injury, inducing nitric oxide (NO) production by stimulated monocytes/macrophages, inhibiting INF- $\gamma$ production by stimulated $\mathrm{CD} 4^{+}$cells, and suppressing the growth of M. tuberculosis [112-114].

Matrix metalloproteinases (MMPs) are proteolytic enzymes that are responsible for extracellular matrix remodeling and for regulating leukocyte migration through the extracellular matrix, which is an important factor in inflammatory processes and infectious diseases [115]. MMPs are produced by many cell types, including lymphocytes, granulocytes, astrocytes, and activated macrophages. In human monocytes, hemozoin enhances the levels of MMP-9 and released IL-1 $\beta$ [116-117]. Serum MMP-8 and TIM-1 levels are significantly higher in the malaria groups compared with the control groups [118]. In a mouse model of experimental cerebral malaria, significant alterations in expressions have been observed, including increases in the mRNAs of MMP3, MMP-8, MMP-13, and MMP-14 in the spleen, MMP-8, MMP-12, MMP-3, MMP-8, MMP-13, and MMP-14 in the liver, and MMP-8 and MMP-13 in the brain [119]. However, VDR knockout mice exhibit an increased influx of inflammatory cells, increased phosphoacetylation of NF- $\mathrm{KB}$ (which is associated with an increase in pro-inflammatory cells), and an upregulation of MMP-2, MMP-9, and MMP-12 in their lungs [120]. The VDR TaqI polymorphism is associated with a decrease in the production of TIMP1 , which is a natural inhibitor of MMP-9 [121]. Calcitriol modulates tissue MMP expression under 
experimental conditions [122], down-regulates MMP9 levels in keratinocytes, and may attenuate the deleterious effects caused by the excessive TNF- $\alpha-$ induced proteolytic activity that is associated with cutaneous inflammation [123]. Calcitriol inhibits both basal and staphylococcus-stimulated production of MMP-9 in human blood monocytes and alveolar macrophages [124]. Moreover, a vitamin D analog has been reported to reduce the expression of MMP-2, MMP-9, VEGF, and PTH-related peptides in Lewis lung carcinoma cells [125]. Calcitriol significantly attenuates $M$. tuberculosis-induced increases in the expression of MMP-7 and MMP-10 and suppresses the secretion of MMP-7 by M. tuberculosis-infected PBMCs. MMP-9 gene expression, secretion, and activity are significantly inhibited, irrespective of the infection status [126]. In another study, calcitriol was found to suppress the production of MMPs (MMP-7 and MMP-9) and enhance the level of TIMP-1 in tuberculosis patients [127]. These studies suggest that calcitriol may play an important role in the pathological process of malaria by down-regulating the level of MMPs and regulating TIMP levels.

The mitogen-activated protein kinase (MAPK) pathways provide a key link between the membranebound receptors that receive these cues and changes in the pattern of gene expression. The three MAPK cascades in mammalian cells are the extracellular signal-regulated kinase (ERK) cascade, the stressactivated protein kinase/c-jun N-terminal kinase (SAPK/JNK) cascade, and the p38MAPK/RK/HOG cascade [128]. MAPK pathways are activated in $P$. falciparum-infected children [129]. Hemozoin induces early cytokine-mediated lysozyme release from human monocytes through p38 MAPK- and NF-kBdependent mechanisms [130]. P. falciparum histones extracted from merozoites directly stimulate the production of IL-8 and other inflammatory mediators by primary human dermal micro-vascular endothelial cells through a signaling pathway that involves the Src family kinases and p38 MAPK [131]. Malaria parasite development in the mosquito is regulated by a conserved MAPK signaling pathway that mediates the effects of an ingested cytokine [132]. ERK and p38 pathway regulate TNF- $\alpha$ and IL-12 production in macrophage-stimulated with purified $P$. falciparum GPI [133]. Human p38 mitogen-activated protein kinase inhibitor drugs, such as pyridinylimidazole RWJ67657 and the pyrrolobenzimidazole RWJ68198, inhibit $P$. falciparum replication [134]. By regulating VDR mRNA expression, the p38 MAPK pathway participates in the mediation of calcium signals and affects lipid accumulation in murine pre-adipocytes [135]. Pretreatment with calcitriol has been shown to inhibit JNK activation by all stressors and to inhibit p38 activation in keratocytes [136]. Zhang et al. [137] demonstrated that the up-regulation of MAPK phosphatase 1 by vitamin $\mathrm{D}$ inhibits the lipopolysaccharide (LPS)-induced activation of p38 and cytokine production in monocytes and macrophages. In another study, the vitamin D analog (24R)-1,24-dihydroxycholecalciferol was found to prevent neuronal damage caused by hydrogen peroxide-induced toxicity in the SH-SY5Y cell line [138]. Interestingly, the neurotoxic effects of hydrogen peroxide are dependent on JNK and p38 MAPK. In addition, the long-tern actions of vitamin D in MCF-7 and LNCaP cancer cells suppress the estradiol-induced activity of ERK-1 MAPK and inhibit cell growth [139].

Prostaglandins (PGs) play a role in inflammatory processes. Cyclooxygenase (COX) participates in the conversion of arachidonic acid into PGs. $\mathrm{PGD}_{2}$ is involved in the pathogenesis of cerebral malaria by inducing HO-1 expression [140]. Malaria-infected mice have increased phospholipase $\mathrm{A}_{2}$ mRNA expression in the spleen; COX1 and COX2 are expressed in the brain [141]. During acute malarial infection, dendritic cells migrate to the spleen and secrete TGF- $\beta, \mathrm{PGE}_{2}$, and IL-10 [142]. COX-2 and IL10 mRNAs have been found to increase primarily during chronic infections in malaria placenta [143]. Calcitriol, which reportedly regulates the expression of several key genes that are involved in PG pathways, decreases PG synthesis [144]. Calcitriol and its analogs have also been shown to selectively inhibit the activity of COX-2 [145]. These findings suggest that vitamin $\mathrm{D}$ plays a role in the anti-inflammatory processes that are associated with malaria.

Vitamin D has a role in reducing oxidative stress in malaria. Reactive oxygen species (ROS) play a major role in various cell-signaling pathways [146]. ROS activate assorted transcription factors and increase the expression of proteins that control cellular transformation, tumor cell survival, tumor cell proliferation and invasion, angiogenesis, and metastasis [147]. Significant increases in malondialdehyde (MDA) and apoptosis were observed in the placental pathology of $P$. bergei-infected mice [97]. Plasma glutathione (GSH) levels are significantly decreased in malaria caused by $P$. falciparum and vivax when compared with controls; the decrease of antioxidant levels is higher in female patients when compared with male patients [148]. GSH and 
superoxide dismutase (SOD) levels are significantly decreased in children with severe malaria [149]. SOD1 is a powerful predictor of disease severity in individuals with different clinical presentations of $P$. vivax malaria [150]. A significant association of the glutathione S-transferases I105V genotype with severe malarial anemia has been observed [151]. Calcitriol administration has been reported to exert a receptormediated effect on the secretion of hydrogen peroxide by human monocytes [152]. In vitro, monocytes gradually lose their ability to produce superoxide when stimulated; the addition of calcitriol, lipopolysaccharide, or lipoteichoic acid (LTA) restored the ability of stimulated monocytes to produce superoxide and increased the oxidative capacity compared to unstimulated monocytes [153]. Calcitriol also protected nonmalignant prostate cells from oxidative stress-induced cell death by preventing ROS-induced cellular injuries [154]. Vitamin D metabolites and analogues have been reported to induce lipoxygenase mRNA expression, lipoxygenase activity, and ROS production in a human bone cell line [155]. Vitamin D also reduces lipid peroxidation and induces SOD activity in the rat hepatic antioxidant system [156]. Astrocytes play a pivotal role in the CNS detoxification pathways, in which GSH is involved in eliminating oxygen- and nitrogen-reactive species such as NO. Calcitriol affects this pathway by enhancing intracellular GSH pools and significantly reduces the nitrite production that is induced by LPS [157].

Nitric oxide synthase (NOS) is an enzyme that is involved in the synthesis of NO, which regulates a variety of important physiological responses, including cell migration, the immune response, and apoptosis [158]. Inducible nitric oxide synthase gene expression is up-regulated in the spleens of malaria-infected mice, and both splenic and peritoneal macrophages produce high levels of NO in vitro in response to stimulation with LPS [159]. An increased NO synthesis in $P$. falciparum malaria can be directly elicited by soluble factor(s) from the blood stages of the parasite, without necessarily requiring the intervention of host cytokines [160]. Genetic variation in the neuronal nitric oxide synthase (nNOS) gene is correlated with susceptibility to cerebral malaria in Indian adults [161]. However, the activation of $1 \alpha$-hydroxylase in macrophages increases the level of calcitriol, which inhibits the expression of inducible NOS (iNOS) and reduces NO production by LPS-stimulated macrophages [162]. Thus, calcitriol production by macrophages may provide protection against the oxidative injuries that are caused by the NO burst. Calcitriol is known to inhibit LPS-induced immune activation in human endothelial cells [163]. In experimental allergic encephalomyelitis, calcitriol inhibits the expression of iNOS in the CNS of rats [164].

\section{Conclusions}

In this paper, the relationship between vitamin D and malaria was reviewed. Genetic studies provide opportunities to determine which proteins link vitamin $\mathrm{D}$ to malaria pathology. Vitamin $\mathrm{D}$ is able to act through numerous non-genomic mechanisms, including protein expression, oxidative stress, inflammation, and cellular metabolism. Therefore, further research on the role of vitamin D in malaria is needed, and a cautious approach is advisable before recommending the widespread use of vitamin $\mathrm{D}$ for malaria.

\section{References}

1. Jüppner H, Kronenberg H (2003) Parathyroid hormone. In: Favus MJ, editor. Primer on the metabolic Bone diseases and disorders of mineral metabolism. American Society for Bone and Mineral Research 117-124.

2. St John A, Davis TM, Binh TQ, Thu LT, Dyer JR, Anh TK (1995) Mineral homoeostasis in acute renal failure complicating severe falciparum malaria. J Clin Endocrinol Metab 80: 2761-2767.

3. Prabha MR, Pereira P, Chowta N, Hegde BM (1998) Clinical implications of hypocalcemia in malaria. Indian J Med Res 108: 62-65.

4. Davis TM, Pukrittayakamee S, Woodhead JS, Holloway P, Chaivisuth B, White NJ (1991) Calcium and phosphate metabolism in acute falciparum malaria. Clin Sci (Lond) 81: 297-304.

5. Sautet J, Vuillet J, Arnaud G (1957) Effects of the immediate adjunction of cod liver oil or vitamin D and calcium biphosphate to antimalarial drugs used in the treatment of Plasmodium berghei infections. II. Bull Soc Pathol Exot Filiales 50: 44-49

6. Sergacheva IuIu, Sokhanenkova TL, Soprunov FF, Lur'e AA (1986) Effect of vitamins D and E on the development of Plasmodium berghei infection in mice. Med Parazitol (Mosk) 4: $15-18$

7. Vial HJ, Thuet MJ, Philippot JR (1982) Inhibition of the in vitro growth of Plasmodium falciparum by $\mathrm{D}$ vitamins and vitamin D-3 derivatives. Mol Biochem Parasitol 5: 189-198.

8. Ray S, Kamath KS, Srivastava R, Raghu D, Gollapalli K, Jain R, Gupta SV, Ray S, Taur S, Dhali S, Gogtay N, Thatte U, Srikanth R, Patankar S, Srivastava S (2012) Serum proteome analysis of vivax malaria: An insight into the disease pathogenesis and host immune response. J Proteomics 75: 3063-3080.

9. Banic DM, Goldberg AC, Pratt-Riccio LR, De OliveiraFerreira J, Santos F, Gras-Masse H, Camus D, Kalil J, DanielRibeiro CT (2002) Human leukocyte antigen class II control of the immune response to p126-derived amino terminal 
peptide from Plasmodium falciparum. Am J Trop Med Hyg 66: 509-515.

10. Shankarkumar U, Devaraj JP, Ghosh K, Karnad D, Anand K, Mohanty D (2002) HLA associations in P. falciparum malaria patients from Mumbai, western India. Indian J Malariol 39: 76-82.

11. Hananantachai H, Patarapotikul J, Ohashi J, Naka I, Looareesuwan S, Tokunaga K (2005) Polymorphisms of the HLA-B and HLA-DRB1 genes in Thai malaria patients. Jpn J Infect Dis 58: 25-28.

12. Osafo-Addo AD, Koram KA, Oduro AR, Wilson M, Hodgson A, Rogers WO. HLA-DRB $1 * 04$ allele is associated with severe malaria in northern Ghana (2008) Am J Trop Med Hyg 78: 251-255.

13. Oliveira-Ferreira J, Pratt-Riccio LR, Arruda M, Santos F, Ribeiro CT, Goldberg AC, Banic DM (2005) HLA class II and antibody responses to circumsporozoite protein repeats of P. vivax (VK210, VK247 and P. vivax-like) in individuals naturally exposed to malaria. Acta Trop 92: 63-69.

14. Storti-Melo LM, da Costa DR, Souza-Neiras WC, Cassiano GC, Couto VS, Soares Ida S, de Carvalho LH, ArevaloHerrera M, Herrera S, Rossit AR, Cordeiro JA, de Mattos LC, Machado RL (2012) Influence of HLA-DRB-1 alleles on the production of antibody against CSP, MSP-1, AMA-1, and DBP in Brazilian individuals naturally infected with Plasmodium vivax. Acta Trop 121: 152-155.

15. Lima-Junior JC, Rodrigues-da-Silva RN, Banic DM, Jiang J, Singh B, Fabrício-Silva GM, Porto LC, Meyer EV, Moreno A, Rodrigues MM, Barnwell JW, Galinski MR, de OliveiraFerreira J (2012) Influence of HLA-DRB1 and HLA-DQB1 alleles on IgG antibody response to the P. vivax MSP-1, MSP-3 $\alpha$ and MSP-9 in individuals from Brazilian endemic area. PLoS One 7: e36419.

16. Kollars TM Jr, Phasuk R, Sattabongkot J (2004) Variation of circumsporozoite 26 and 29 genotypes of Plasmodium falciparum infecting patients and association with HLA-DQA allotypes in western Thailand. J Parasitol 90: 182-184.

17. Busson $\mathrm{M}, \mathrm{Vu}$ Trieu A, Labelle P, Pham-Van K, Ho-Quang H, Bouteiller AM, Bleux H, Charron D, Hors J (2002) HLADRB1 and DQB1 allele distribution in the Muong population exposed to malaria in Vietnam. Tissue Antigens 59: 470-474.

18. May J, Lell B, Luty AJ, Meyer CG, Kremsner PG (2001) HLA-DQB1*0501-restricted Th1 type immune responses to Plasmodium falciparum liver stage antigen 1 protect against malaria anemia and reinfections. J Infect Dis 183: 168-172.

19. Tokuda N, Levy RB (1996) 1,25-hydroxyvitamin $\mathrm{D}_{3}$ stimulates phagocytosis but suppresses HLA-DR and CD13 antigen expression in human mononuclear phagocytes. Proc Soc Exp Biol Med 211: 244-250.

20. Tokuda N, Mizuki N, Kasahara M, Levy RB (1992) 1,25hydroxyvitamin $\mathrm{D}_{3}$ down-regulation of HLA-DR on human peripheral blood monocytes. Immunol 75:349-354.

21. Tamaki K, Saitoh A, Kubota Y (1990) 1,25-hydroxyvitamin $\mathrm{D}_{3}$ decreases the interferon-gamma (IFN-gamma) induced HLA-DR expression but not intercellular adhesion molecule 1 (ICAM-1) on human keratinocytes. Reg Immunol 3: 223-227.

22. Tone T, Eto H, Katou T, Otani F, Nishiyama S (1993) 1 alpha,25-dihydroxy vitamin $\mathrm{D}_{3}$ modulation of HLA-DR mRNA induced by gamma-interferon in cultured epithelial tumor cell lines. J Dermatol 20: 581-584.

23. Penna G, Adorini L (2000) 1 Alpha,25-dihydroxyvitamin $\mathrm{D}_{3}$ inhibits differentiation, maturation, activation, and survival of dendritic cells leading to impaired alloreactive $\mathrm{T}$ cell activation. J Immunol 164: 2405-2411.

24. Penna G, Adorini L (2001) Inhibition of costimulatory pathways for T-cell activation by 1,25-dihydroxyvitamin $\mathrm{D}_{3}$. Transplant Proc 33: 2083-2084.

25. Ferreira GB, Overbergh L, Verstuyf A, Mathieu C (2013) $1 \alpha, 25$-Dihydroxyvitamin $\mathrm{D}_{3}$ and its analogs as modulators of human dendritic cells: A comparison dose-titration study. J Steroid Biochem Mol Biol 136: 160-165.

26. Zügel U, Steinmeyer A, May E, Lehmann M, Asadullah K (2009) Immunomodulation by a novel, dissociated Vitamin D analogue. Exp Dermatol 18: 619-627.

27. Scherberich J, Kellermeyer M, Ried C, Hartinger A (2005) 1alpha-calcidol modulates major human monocyte antigens and toll-like receptors TRL2 and TRL4 in vitro. Eur J Med Res 10: 179-182.

28. Bartels LE, Hvas CL, Agnholt J, Dahlerup JF, Agger R (2010) Human dendritic cell antigen presentation and chemotaxis are inhibited by intrinsic 25 -hydroxy vitamin D activation. Int Immunopharmacol 10: 922-928.

29. Özdemir BH, Özdemir AA, Colak T, Sezer S, Haberal M (2011) The influence of tubular phenotypic changes on the development of diffuse interstitial fibrosis in renal allografts. Transplant Proc 43: 527-529.

30. McCall MB, Netea MG, Hermsen CC, Jansen T, Jacobs L, Golenbock D, van der Ven AJ, Sauerwein RW (2007) Plasmodium falciparum infection causes proinflammatory priming of human TLR responses. J Immunol 179: 162-171.

31. Loharungsikul S, Troye-Blomberg $\mathrm{M}$, Amoudruz $\mathrm{P}$, Pichyangkul S, Yongvanitchit K, Looareesuwan S, Mahakunkijcharoen Y, Sarntivijai S, Khusmith S (2008) Expression of toll-like receptors on antigen-presenting cells in patients with falciparum malaria. Acta Trop 105: 10-15.

32. Hartgers FC, Obeng BB, Voskamp A, Larbi IA, Amoah AS, Luty AJ, Boakye D, Yazdanbakhsh M (2008) Enhanced Tolllike receptor responsiveness associated with mitogenactivated protein kinase activation in Plasmodium falciparuminfected children. Infect Immun 76: 5149-5157.

33. Coban $\mathrm{C}$, Ishii KJ, Kawai T, Hemmi H, Sato S Uematsu S, Yamamoto M, Takeuchi O, Itagaki S, Kumar N, Horii T, Akira S (2005) Toll-like receptor 9 mediates innate immune activation by the malaria pigment hemozoin. J Exp Med 201: 19-25.

34. Parroche P, Lauw FN, Goutagny N, Latz E, Monks BG, Visintin A, Halmen KA, Lamphier M, Olivier M, Bartholomeu DC, Gazzinelli RT, Golenbock DT (2007) Malaria hemozoin is immunologically inert but radically enhances innate responses by presenting malaria DNA to Toll-like receptor 9. Proc Natl Acad Sci U S A 104: 19191924.

35. Franklin BS, Ishizaka ST, Lamphier M, Gusovsky F, Hansen H, Rose J, Zheng W, Ataíde MA, de Oliveira RB, Golenbock DT, Gazzinelli RT (2011) Therapeutical targeting of nucleic acid-sensing Toll-like receptors prevents experimental cerebral malaria. Proc Natl Acad Sci U S A 108: 3689-3694.

36. Hamann L, Bedu-Addo G, Eggelte TA, Schumann RR, Mockenhaupt FP (2010) The toll-like receptor 1 variant S248N influences placental malaria. Infect Genet Evol 10: 785-789.

37. Mockenhaupt FP, Cramer JP, Hamann L, Stegemann MS, Eckert J, Oh NR, Otchwemah RN, Dietz E, Ehrhardt S, Schröder NW, Bienzle U, Schumann RR (2006) Toll-like receptor (TLR) polymorphisms in African children: Common 
TLR-4 variants predispose to severe malaria. Proc Natl Acad Sci U S A 103: 177-182.

38. Esposito S, Molteni CG, Zampiero A, Baggi E, Lavizzari A, Semino M, Daleno C, Groppo M, Scala A, Terranova L, Miozzo M, Pelucchi C, Principi N (2012) Role of polymorphisms of toll-like receptor (TLR) 4, TLR9, tollinterleukin 1 receptor domain containing adaptor protein (TIRAP) and FCGR2A genes in malaria susceptibility and severity in Burundian children. Malar J 11: 196.

39. Mockenhaupt FP, Hamann L, von Gaertner C, Bedu-Addo G, von Kleinsorgen C, Schumann RR, Bienzle U (2006) Common polymorphisms of toll-like receptors 4 and 9 are associated with the clinical manifestation of malaria during pregnancy. J Infect Dis 194: 184-188.

40. Greene JA, Moormann AM, Vulule J, Bockarie MJ, Zimmerman PA, Kazura JW (2009) Toll-like receptor polymorphisms in malaria-endemic populations. Malar $\mathrm{J} 8$ : 50.

41. Roth CL, Elfers CT, Figlewicz DP, Melhorn SJ, Morton GJ, Hoofnagle A, Yeh MM, Nelson JE, Kowdley KV (2012) Vitamin D deficiency in obese rats exacerbates NAFLD and increases hepatic resistin and toll-like receptor activation. Hepatology 55: 1103-1111.

42. Sadeghi K, Wessner B, Laggner U, Ploder M, Tamandl D, Friedl J, Zügel U, Steinmeyer A, Pollak A, Roth E, BoltzNitulescu G, Spittler A (2006) Vitamin $\mathrm{D}_{3}$ down-regulates monocyte TLR expression and triggers hyporesponsiveness to pathogen-associated molecular patterns. Eur J Immunol 36: 361-370.

43. Dickie L, Church L, Coulthard L, Mathews R, Emery P, McDermott M (2010) Vitamin $\mathrm{D}_{3}$ downregulates intracellular toll-like receptor 9 expression and toll-like receptor 9-induced IL-6 production in human monocytes. Rheumatol 48: 14661471.

44. Liu PT, Stenger S, Li H, Wenzel L, Tan BH, Krutzik SR, Ochoa MT, Schauber J, Wu K, Meinken C, Kamen DL, Wagner M, Bals R, Steinmeyer A, Zügel U, Gallo RL, Eisenberg D, Hewison M, Hollis BW, Adams JS, Bloom BR, Modlin RL (2006) Toll-like receptor triggering of a vitamin D-mediated human antimicrobial response. Science 311: 1770-1773.

45. Grochot-Przeczek A, Dulak J, Jozkowicz A (2012) Haem oxygenase-1: non-canonical roles in physiology and pathology. Clin Sci (Lond) 122: 93-103.

46. Hascalovici JR, Vaya J, Khatib S, Holcroft CA, Zukor H, Song W, Arvanitakis Z, Bennett DA, Schipper HM (2009) Brain sterol dys-regulation in sporadic $\mathrm{AD}$ and MCI: Relationship to heme oxygenase-1. J Neurochem 110: 12411253.

47. Baranano DE, Snyder SH (2001) Neural roles for heme oxygenase: contrasts to nitric oxide synthase. Proc Natl Acad Sci U S A 98: 10996-11002.

48. Sinnis P, Ernst JD (2008) CO-opting the host HO-1 pathway in tuberculosis and malaria. Cell Host Microbe 3: 277-279.

49. Schluesener HJ, Kremsner PG, Meyermann R (2001) Heme oxygenase-1 in lesions of human cerebral malaria. Acta Neuropathol 101: 65-68.

50. Clark IA, Awburn MM, Harper CG, Liomba NG, Molyneux ME (2003) Induction of HO-1 in tissue macrophages and monocytes in fatal falciparum malaria and sepsis. Malar J 2: 41.

51. Epiphanio S, Mikolajczak SA, Gonçalves LA, Pamplona A, Portugal S, Albuquerque S, Goldberg M, Rebelo S, Anderson
DG, Akinc A, Vornlocher HP, Kappe SH, Soares MP, Mota MM (2008) Heme oxygenase-1 is an anti-inflammatory host factor that promotes murine plasmodium liver infection. Cell Host Microbe 3: 331-338.

52. Takeda M, Kikuchi M, Ubalee R, Na-Bangchang K, Ruangweerayut R, Shibahara S, Imai S, Hirayama K (2005) Microsatellite polymorphism in the heme oxygenase-1 gene promoter is associated with susceptibility to cerebral malaria in Myanmar. Jpn J Infect Dis 58: 268-271.

53. Mendonça VR, Luz NF, Santos NJ, Borges VM, Gonçalves MS, Andrade BB, Barral-Netto M (2012) Association between the haptoglobin and heme oxygenase 1 genetic profiles and soluble CD163 in susceptibility to and severity of human malaria. Infect Immun 80: 1445-1454.

54. Walther M, De Caul A, Aka P, Njie M, Amambua-Ngwa A, Walther B, Predazzi IM, Cunnington A, Deininger S, Takem EN, Ebonyi A, Weis S, Walton R, Rowland-Jones S, Sirugo G, Williams SM, Conway DJ (2012) HMOX1 gene promoter alleles and high HO-1 levels are associated with severe malaria in Gambian children. PLoS Pathog 8: e1002579.

55. Oermann E, Bidmon H-J, Witte O-W, Zilles K (2004) Effects of 1 1 ,25-didroxyvitamin $\mathrm{D}_{3}$ on the expression of HO-1 and GFAP in glial cells of the photothrombotically lesioned cerebral cortex. J Chem Neuroanat 28: 225-238.

56. Turner GD, Morrison H, Jones M, Davis TM, Looareesuwan S, Buley ID, Gatter KC, Newbold CI, Pukritayakamee S, Nagachinta B, et al (1994) An immunohistochemical study of the pathology of fatal malaria. Evidence for widespread endothelial activation and a potential role for intercellular adhesion molecule-1 in cerebral sequestration. Am J Pathol 145: 1057-1069.

57. Jain V, Lucchi NW, Wilson NO, Blackstock AJ, Nagpal AC, Joel PK, Singh MP, Udhayakumar V, Stiles JK, Singh N (2011) Plasma levels of angiopoietin-1 and -2 predict cerebral malaria outcome in Central India. Malar J 10: 383.

58. Conroy AL, Phiri H, Hawkes M, Glover S, Mallewa M, Seydel KB, Taylor TE, Molyneux ME, Kain KC (2010) Endothelium-based biomarkers are associated with cerebral malaria in Malawian children: a retrospective case-control study. PLoS One 5: e15291.

59. Conroy AL, Glover SJ, Hawkes M, Erdman LK, Seydel KB, Taylor TE, Molyneux ME, Kain KC (2012) Angiopoietin-2 levels are associated with retinopathy and predict mortality in Malawian children with cerebral malaria: a retrospective casecontrol study. Crit Care Med 40: 952-959.

60. Silver KL, Zhong K, Leke RG, Taylor DW, Kain KC (2010) Dysregulation of angiopoietins is associated with placental malaria and low birth weight. PLoS One 5: e9481.

61. Yeo TW, Lampah DA, Gitawati R, Tjitra E, Kenangalem E, Piera K, Price RN, Duffull SB, Celermajer DS, Anstey NM (2008) Angiopoietin-2 is associated with decreased endothelial nitric oxide and poor clinical outcome in severe falciparum malaria. Proc Natl Acad Sci U S A 105: 1709717102.

62. Hawkes M, Opoka RO, Namasopo S, Miller C, Thorpe KE, Lavery JV, Conroy AL, Liles WC, John CC, Kain KC (2011) Inhaled nitric oxide for the adjunctive therapy of severe malaria: protocol for a randomized controlled trial. Trials 12: 176.

63. Bernardi RJ, Johnson CS, Modzelewski RA, Trump DL (2002) Antiproliferative effects of 1 $1 \alpha, 25$-dihydroxyvitamin $\mathrm{D}_{3}$ and vitamin D analogs on tumor-derived endothelial cells. Endocrinology 143: 2508-2514. 
64. Kanda S, Mochizuki Y, Miyata Y, Kanetake H, Yamamoto N (2002) Effects of vitamin $\mathrm{D}_{3}$-binding protein-derived macrophage activating factor (GcMAF) on angiogenesis. J Natl Cancer Inst 94: 1311-1319.

65. Kaiko GE, Horvat JC, Beagley KW, Hansbro PM (2008) Immunological decision-making: how does the immune system decide to mount a helper T-cell response? Immunology 123: 326-338.

66. Schlotmann T, Waase I, Jülch C, Klauenberg U, MüllerMyhsok B, Dietrich M, Fleischer B, Bröker BM (2000) CD4 alphabeta $\mathrm{T}$ lymphocytes express high levels of the $\mathrm{T}$ lymphocyte antigen CTLA-4 (CD152) in acute malaria. J Infect Dis 182: 367-370.

67. Braun N, Marfo Y, Von Gärtner C, Burchard GD, Zipfel PF, Browne NE, Fleischer B, Bröker BM (2003) CTLA-4 positive $\mathrm{T}$ cells in contrast to procalcitonin plasma levels discriminate between severe and uncomplicated Plasmodium falciparum malaria in Ghanaian children. Trop Med Int Health 8: 10181024.

68. Bueno LL, Morais CG, Araújo FF, Gomes JA, CorrêaOliveira R, Soares IS, Lacerda MV, Fujiwara RT, Braga EM (2010) Plasmodium vivax: induction of $\mathrm{CD} 4^{+} \mathrm{CD} 25^{+} \mathrm{FoxP}^{+}$ regulatory $\mathrm{T}$ cells during infection are directly associated with level of circulating parasites. PLoS One 5: e9623.

69. Jacobs T, Graefe SE, Niknafs S, Gaworski I, Fleischer B (2002) Murine malaria is exacerbated by CTLA-4 blockade. J Immunol 169: 2323-2329.

70. Jacobs T, Plate T, Gaworski I, Fleischer B (2004) CTLA-4dependent mechanisms prevent $\mathrm{T}$ cell induced-liver pathology during the erythrocyte stage of Plasmodium berghei malaria. Eur J Immunol 34: 972-980.

71. Lepenies B, Gaworski I, Tartz S, Langhorne J, Fleischer B, Jacobs T (2007) CTLA-4 blockade differentially influences the outcome of non-lethal and lethal Plasmodium yoelii infections. Microbes Infect 9: 687-694

72. Todryk SM, Walther M, Bejon P, Hutchings C, Thompson FM, Urban BC, Porter DW, Hill AV (2009) Multiple functions of human $\mathrm{T}$ cells generated by experimental malaria challenge. Eur J Immunol 39: 3042-3051.

73. Daniel C, Sartory NA, Zahn N, Radeke HH, Stein JM (2008) Immune modulatory treatment of trinitrobenzene sulfonic acid colitis with calcitriol is associated with a change of a T helper (Th) 1/Th17 to a Th2 and regulatory T cell profile. J Pharmacol Exp Ther 324: 23-33.

74. Jeffery LE, Burke F, Mura M, Zheng Y, Qureshi OS, Hewison M, Walker LS, Lammas DA, Raza K, Sansom DM (2009) 1,25-Dihydroxyvitamin $\mathrm{D}_{3}$ and IL-2 combine to inhibit $\mathrm{T}$ cell production of inflammatory cytokines and promote development of regulatory $\mathrm{T}$ cells expressing CTLA4 and FoxP3. J Immunol 183: 5458-5467.

75. Fabri M, Stenger S, Shin DM, Yuk JM, Liu PT, Realegeno S, Lee HM, Krutzik SR, Schenk M, Sieling PA, Teles R, Montoya D, Iyer SS, Bruns H, Lewinsohn DM, Hollis BW, Hewison M, Adams JS, Steinmeyer A, Zügel U, Cheng G, Jo EK, Bloom BR, Modlin RL (2011) Vitamin D is required for IFN-gamma-mediated antimicrobial activity of human macrophages. Sci Transl Med 3: 104ra102.

76. Ting JP, Davis PK (2005) CATERPILLER: a novel gene family important in immunity, cell death, and diseases. Annu Rev Immunol 23: 387-414.

77. Le Bourhis L, Benko S, Girardin SE (2007) Nod1 and Nod2 in innate immunity and human inflammatory disorders. Biochem Soc Trans 35: 1479-1484.
78. Franchi L, Park JH, Shaw MH, Marina-Garcia N, Chen G, Kim YG, Núñez G (2008) Intracellular NOD-like receptors in innate immunity, infection and disease. Cell Microbiol 10: 18.

79. Tada H, Aiba S, Shibata K, Ohteki T, Takada H (2005) Synergistic effect of Nod1 and Nod2 agonists with toll-like receptor agonists on human dendritic cells to generate interleukin-12 and $\mathrm{T}$ helper type 1 cells. Infect Immun 73: 7967-7976.

80. Magalhaes JG, Fritz JH, Le Bourhis L, Sellge G, Travassos LH, Selvanantham T, Girardin SE, Gommerman JL, Philpott DJ (2008) Nod2-dependent Th2 polarization of antigenspecific immunity. J Immunol 181: 7925-7935.

81. Kobayashi KS, Chamaillard M, Ogura Y, Henegariu O, Inohara N, Nuñez G, Flavell RA (2005) Nod2-dependent regulation of innate and adaptive immunity in the intestinal tract. Science 307: 731-734.

82. Viala J, Chaput C, Boneca IG, Cardona A, Girardin SE, Moran AP, Athman R, Mémet S, Huerre MR, Coyle AJ, DiStefano PS, Sansonetti PJ, Labigne A, Bertin J, Philpott DJ, Ferrero RL (2004) Nod1 responds to peptidoglycan delivered by the Helicobacter pylori cag pathogenicity island. Nat Immunol 5: 1166-1174.

83. Ockenhouse CF, Hu WC, Kester KE, Cummings JF, Stewart A, Heppner DG, Jedlicka AE, Scott AL, Wolfe ND, Vahey M, Burke DS (2006) Common and divergent immune response signaling pathways discovered in peripheral blood mononuclear cell gene expression patterns in presymptomatic and clinically apparent malaria. Infect Immun 74: 5561-5573.

84. Finney CA, Lu Z, LeBourhis L, Philpott DJ, Kain KC (2009) Disruption of Nod-like receptors alters inflammatory response to infection but does not confer protection in experimental cerebral malaria. Am J Trop Med Hyg 80: 718-722.

85. Shio MT, Eisenbarth SC, Savaria M, Vinet AF, Bellemare MJ, Harder KW, Sutterwala FS, Bohle DS, Descoteaux A, Flavell RA, Olivier M (2009) Malarial hemozoin activates the NLRP3 inflammasome through Lyn and Syk kinases. PLoS Pathog 5: e1000559.

86. John CC, Panoskaltsis-Mortari A, Opoka RO, Park GS, Orchard PJ, Jurek AM, Idro R, Byarugaba J, Boivin MJ (2008) Cerebrospinal fluid cytokine levels and cognitive impairment in cerebral malaria. Am J Trop Med Hyg 78: 198205.

87. Ong'echa JM, Raballah EO, Kempaiah PM, Anyona SB, Were T, Davenport GC, Konah S, Vulule JM, Ouma C, Hittner JB, Perkins DJ (2011) Polymorphic variability in the $3^{\prime}$ untranslated region (UTR) of IL12B is associated with susceptibility to severe anaemia in Kenyan children with acute Plasmodium falciparum malaria. BMC Genet 12: 69.

88. Wang TT, Dabbas B, Laperriere D, Bitton AJ, Soualhine H, Tavera-Mendoza LE, Dionne S, Servant MJ, Bitton A, Seidman EG, Mader S, Behr MA, White JH (2010) Direct and indirect induction by 1,25-dihydroxyvitamin $\mathrm{D}_{3}$ of the NOD2/CARD15-Defensin b2 innate immune pathway defective in Crohn Disease. J Biol Chem 285: 2227-2231.

89. Verway M, Behr MA, White JH (2010) Vitamin D, NOD2, autophagy and Crohn's disease. Expert Rev Clin Immunol 6: 505-508.

90. Froicu M, Cantorna MT (2007) Vitamin D and the vitamin D receptor are critical for control of the innate immune response to colonic injury. BMC Immunol 8: 5.

91. Khoo AL, Chai LY, Koenen HJ, Sweep FC, Joosten I, Netea MG, van der Ven AJ (2011) Regulation of cytokine responses 
by seasonality of vitamin D status in healthy individuals. Clin Exp Immunol 164: 72-79.

92. Wang AP, Li X, Chao C, Huang G, Liu BL, Peng J, Zhou ZG (2012) $1 \alpha, 25(\mathrm{OH})_{2} \mathrm{D}_{3}$ protects pancreatic $\beta$-cell line from cytokine-induced apoptosis and impaired insulin secretion. Zhonghua Yi Xue Za Zhi 92: 695-699

93. Zhang T, Saghatelian A. Emerging roles of lipids in BCL-2 family-regulated apoptosis. Biochim Biophys Acta. 2013 Mar 21. pii: S1388-1981(13)00059-0. doi: 10.1016/j.bbalip.2013.03.001. [Epub ahead of print]

94. Wu CC, Bratton SB (2013) Regulation of the intrinsic apoptosis pathway by reactive oxygen species. Antioxid Redox Signal 19: 546-58.

95. Kumar KA, Babu PP (2002) Mitochondrial anomalies are associated with the induction of intrinsic cell death proteins$\operatorname{Bcl}(2)$, Bax, cytochrome-c and p53 in mice brain during experimental fatal murine cerebral malaria. Neurosci Lett 329: 319-323.

96. Guha M, Maity P, Choubey V, Mitra K, Reiter RJ, Bandyopadhyay U (2007) Melatonin inhibits free radicalmediated mitochondrial-dependent hepatocyte apoptosis and liver damage induced during malarial infection. J Pineal Res 43: 372-381.

97. Sharma L, Kaur J, Shukla G (2012) Role of oxidative stress and apoptosis in the placental pathology of Plasmodium berghei infected mice. PLoS One 7: e32694

98. Wennicke K, Debierre-Grockiego F, Wichmann D, Brattig NW, Pankuweit S, Maisch B, Schwarz RT, Ruppert V (2008) Glycosylphosphatidylinositol-induced cardiac myocyte death might contribute to the fatal outcome of Plasmodium falciparum malaria. Apoptosis 13: 857-866.

99. Zhang A, Wang Y, Xie H, Zheng S (2007) Calcitriol inhibits hepatocyte apoptosis in rat allograft by regulating apoptosisassociated genes. Int Immunopharmacol 7: 1122-1128.

100. Xiang W, He XJ, Ma YL, Yi ZW, Cao Y, Zhao SP, Yang JF, Ma ZC, Wu M, Fu SM, Ma JL, Wang J, Zheng W, Kang H (2011) $1,25(\mathrm{OH})_{2} \mathrm{D}_{3}$ influences endothelial cell proliferation, apoptosis and endothelial nitric oxide synthase expression of aorta in apolipoprotein E-deficient mice. Zhonghua Er Ke Za Zhi 49: 829-833

101. Zou MS, Yu J, Nie GM, He WS, Luo LM, Xu HT (2010) 1, 25-dihydroxyvitamin $\quad \mathrm{D}_{3}$ decreases adriamycin-induced podocyte apoptosis and loss. Int J Med Sci 7: 290-299.

102. Liu HZ, Gong JP, Wu CX, Peng Y, Li XH, You HB (2005) The U937 cell line induced to express CD14 protein by 1,25 dihydroxyvitamin $\mathrm{D}_{3}$ and be sensitive to endotoxin stimulation. Hepatobiliary Pancreat Dis Int 4: 84-89.

103. Clark IA, Allison AC, Cox FE (1976) Protection of mice against Babesia and Plasmodium with BCG. Nature 259: 309311.

104. Ferraroni JJ, Douglass TG, Speer CA (1986) Effects of Mycobacterium bovis BCG, bacterial lipopolysaccharide and hydrocortisone on the development of immunity to Plasmodium berghei. Rev Inst Med Trop Sao Paulo 28: 36-45.

105. Smrkovski LL (1981) Effect of route of Mycobacterium bovis BCG administration on induction of suppression of sporozoite immunity in rodent malaria. Infect Immun 31: 408-412.

106. Roth A, Gustafson P, Nhaga A, Djana Q, Poulsen A, Garly ML, Jensen H, Sodemann M, Rodriques A, Aaby P (2005) BCG vaccination scar associated with better childhood survival in Guinea-Bissau. BCG vaccination scar associated with better childhood survival in Guinea-Bissau. Int $\mathrm{J}$ Epidemiol 34: 540-547.
107. Arama C, Waseem S, Fernández C, Assefaw-Redda Y, You L, Rodriguez A, Radošević K, Goudsmit J, Kaufmann SH, Reece ST, Troye-Blomberg M (2012) A recombinant Bacille Calmette-Guérin construct expressing the Plasmodium falciparum circumsporozoite protein enhances dendritic cell activation and primes for circumsporozoite-specific memory cells in BALB/c mice. Vaccine 30: 5578-5584.

108. Rapeah S, Dhaniah M, Nurul AA, Norazmi MN (2010) Phagocytic activity and pro-inflammatory cytokines production by the murine macrophage cell line J774A.1 stimulated by a recombinant BCG (rBCG) expressing the MSP1-C of Plasmodium falciparum. Trop Biomed 27: 461469.

109. Nurul AA, Norazmi MN (2011) Immunogenicity and in vitro protective efficacy of recombinant Mycobacterium bovis bacille Calmette Guerin (rBCG) expressing the $19 \mathrm{kDa}$ merozoite surface protein-1 (MSP-1(19)) antigen of Plasmodium falciparum. Parasitol Res 108: 887-897.

110. Teo WH, Nurul AA, Norazmi MN (2012) Immunogenicity of recombinant BCG-based vaccine expressing the $22 \mathrm{kDa}$ of serine repeat antigen (SE22) of Plasmodium falciparum. Trop Biomed 29: 239-253.

111. Lalor M, Floyd S, Gorak-Stolinska P, Weir R, Blitz R, Branson K, Fine PE, Dockrell HM (2011) BCG vaccination: a role for vitamin D? PLos ONE 6: 216709.

112. Rhodes SG, Terry LA, Hope J, Hewinson RG, Vordermeier HM (2003) 1,25-dihydroxyvitamin $\mathrm{D}_{3}$ and development of tuberculosis in cattle. Clin Diagn Lab Immunol 10: 11291135.

113. Ametaj B, Beitz D, Reihardt T, Nonnecke B (1966) 1,25dihydroxyvitamin $\mathrm{D}_{3}$ inhibits secretion of interferon-gamma by mitogen- and antigen-stimulated bovine mononuclear leukocytes. Vet Immunol Imnunopathol 52: 77-90.

114. Rockett K, Brookes R, Udalova I, Vidal V, Hill A, Kwiatkowski D (1988) 1,25-hydroxyvitamin $\mathrm{D}_{3}$ induces nitric oxide synthase and suppresses growth of Mycobacterium tuberculosis in a human macrophage-like cell line. Infect Immun 66: 5314-5321.

115. Marco M, Fortin C, Fulop T (2013) Membrane-type matrix metalloproteinases: key mediators of leukocyte function. J Leukoc Biol 94: 237-246.

116. Prato M, Gallo V, Giribaldi G, Aldieri E, Arese P (2010) Role of the NF- $\mathrm{BB}$ transcription pathway in the haemozoin- and 15HETE-mediated activation of matrix metalloproteinase-9 in human adherent monocytes. Cell Microbiol 12: 1780-1791.

117. Prato M, D'Alessandro S, Van den Steen PE, Opdenakker G, Arese P, Taramelli D, Basilico N (2011) Natural haemozoin modulates matrix metalloproteinases and induces morphological changes in human microvascular endothelium. Cell Microbiol 13: 1275-1285.

118. Dietmann A, Helbok R, Lackner P, Issifou S, Lell B, Matsiegui PB, Reindl M, Schmutzhard E, Kremsner PG (2008) Matrix metalloproteinases and their tissue inhibitors (TIMPs) in Plasmodium falciparum malaria: serum levels of TIMP-1 are associated with disease severity. J Infect Dis 197: 1614-1620.

119. Van den Steen PE, Van Aelst I, Starckx S, Maskos K, Opdenakker G, Pagenstecher A (2006) Matrix metalloproteinases, tissue inhibitors of MMPs and TACE in experimental cerebral malaria. Lab Invest 86: 873-888.

120. Sundar I, Hwang J, Wu S, Sun J, Rahman I (2011) Deletion of vitamin $\mathrm{D}$ receptor leads to premature emphysema/COPD by 
increased matrix metalloproteinase and lymphoid aggregates formation. Biochem Biophys Res Commun 406: 127-133.

121. Timms P, Mannan N, Hitman G (2002) Circulating MMP9, vitamin $\mathrm{D}$ and variation in the TIMP-1 response with VDR genotype: mechanisms for inflammatory damage in chronic disorders? Q J Med 95: 787-796.

122. Dean DD, Schwartz Z, Schmitz J, Muniz OE, Lu Y, Calderon F, Howell DS, Boyan BD (1996) Vitamin D regulation of metalloproteinase activity in matrix vesicles. Connect Tissue Res 35: 331-336.

123. Bahar-Shany K, Ravid A, Koren R (2010) Upregulation of MMP-production by TNFalpha in keratinocytes and its attenuation by vitamin D. J Cell Physiol 222: 729-737.

124. Lacraz S, Dayer J, Nicod L, Welgus H (1994) 1,25dihydroxyvitamin $\mathrm{D}_{3}$ dissociates production of interstitial collagenase and $92-\mathrm{kDa}$ gelatinase in human mononuclear phagocytes. J Biol Chem 269: 6485-6490.

125. Nakagawa K, Sasaki Y, Kato S, Kubodera N, Okano T (2005) 22-Oxa-1 $\alpha, 25$-dihydroxyvitamin $\mathrm{D}_{3}$ inhibits metastasis and angiogenesis in lung cancer. Carcinogenesis 26: 1044-1054.

126. Coussens A, Timms P, Boucher B, Venton T, Ashcroft A, Skolimowska KH, Newton SM, Wilkinson KA, Davidson RN, Griffiths CJ, Wilkinson RJ, Martineau AR (2009) 1 1 ,25dihydroxyvitamin $\mathrm{D}_{3}$ inhibits matrix metalloproteinases induced by Mycobacterium tuberculosis infection. Immunol 127: 539-548.

127. Anand S, Selvaraj P (2009) Effect of 1,25 dihydroxyvitamin $\mathrm{D}_{3}$ on matrix metalloproteinases MMP-7, MMP-9 and the inhibitor TIMP-1 in pulmonary tuberculosis 133: 126-131.

128. Hipskind RA, Bilbe G (1998) MAP kinase signaling cascades and gene expression in osteoblasts. Front Biosci 3: d804-816.

129. Hartgers FC, Obeng BB, Voskamp A, Larbi IA, Amoah AS, Luty AJ, Boakye D, Yazdanbakhsh M (2008) Enhanced Tolllike receptor responsiveness associated with mitogenactivated protein kinase activation in Plasmodium falciparuminfected children. Infect Immun 76: 5149-5157.

130. Polimeni M, Valente E, Aldieri E, Khadjavi A, Giribaldi G, Prato M (2012) Haemozoin induces early cytokine-mediated lysozyme release from human monocytes through p38 MAPK- and NF-kappaB-dependent mechanisms. PLoS One 7: e39497.

131. Gillrie MR, Lee K, Gowda DC, Davis SP, Monestier M, Cui L, Hien TT, Day NP, Ho M (2012) Plasmodium falciparum histones induce endothelial proinflammatory response and barrier dysfunction. Am J Pathol 180: 1028-1039.

132. Surachetpong W, Singh N, Cheung KW, Luckhart S (2009) MAPK ERK signaling regulates the TGF-betal-dependent mosquito response to Plasmodium falciparum. PLoS Pathog 5: e1000366.

133. Zhu J, Wu X, Goel S, Gowda NM, Kumar S, Krishnegowda G, Mishra G, Weinberg R, Li G, Gaestel M, Muta T, Gowda DC (2009) MAPK-activated protein kinase 2 differentially regulates plasmodium falciparum glycosylphosphatidylinositol-induced production of tumor necrosis factor-\{alpha $\}$ and interleukin-12 in macrophages. J Biol Chem 284: 15750-15761.

134. Brumlik MJ, Nkhoma S, Kious MJ, Thompson GR 3rd, Patterson TF, Siekierka JJ, Anderson TJ, Curiel TJ (2011) Human p38 mitogen-activated protein kinase inhibitor drugs inhibit Plasmodium falciparum replication. Exp Parasitol 128: 170-175.

135. Sun C, Qi R, Wang L, Yan J, Wang Y (2012) p38 MAPK regulates calcium signal-mediated lipid accumulation through changing VDR expression in primary preadipocytes of mice. Mol Biol Rep 39: 3179-3184.

136. Ravid A, Rubinstein E, Gamady A, Rotem C, Liberman UA, Koren R (2002) Vitamin D inhibits the activation of stressactivated protein kinases by physiological and environmental stresses in keratinocytes. J Endocrinol 173: 525-532.

137. Zhang Y, Leung DY, Richers BN, Liu Y, Remigio LK, Riches DW, Goleva E (2012) Vitamin D inhibits monocyte/macrophage proinflammatory cytokine production by targeting MAPK phosphatase-1. J Immunol 188: 21272135.

138. Tetich M, Kutner A, Leskiewicz M, Budziszewska B, Lasoń W (2004) Neuroprotective effects of (24R)-1,24dihydroxycholecalciferol in human neuroblastoma SH-SY5Y cell line. J Steroid Biochem Mol Biol 89-90: 365-370.

139. Liakhovich AV, Aksenov NL, Tuokhima P, Mikhel'son VM (2000) [Long-term action of vitamin D suppresses the estradiol-induced activity of erk-1 MAPK and proliferation of MCF-7 and LNCaP cancer cells]. Tsitologiia 42: 977-982 [Article in Russian].

140. Kuesap J, Na-Bangchang K (2010) Possible role of heme oxygenase-1 and prostaglandins in the pathogenesis of cerebral malaria: heme oxygenase-1 induction by prostaglandin $\mathrm{D}_{2}$ and metabolite by a human astrocyte cell line. Korean J Parasitol 48: 15-21.

141. Xiao L, Patterson PS, Yang C, Lal AA (1999) Role of eicosanoids in the pathogenesis of murine cerebral malaria. Am J Trop Med Hyg 60: 668-673.

142. Ocaña-Morgner C, Wong KA, Lega F, Dotor J, Borras-Cuesta F, Rodriguez A (2007) Role of TGF-beta and PGE2 in T cell responses during Plasmodium yoelii infection. Eur J Immunol 37: $1562-1574$.

143. Sarr D, Aldebert D, Marrama L, Frealle E, Gaye A, Brahim HO, Niang M, Dangou JM, Mercereau-Puijalon O, Lehesran JY, Jambou R (2010) Chronic infection during placental malaria is associated with up-regulation of cycloxygenase- 2 . Malar J 9: 45.

144. Moreno J, Krishnan AV, Swami S, Nonn L, Peehl DM, Feldman D (2005) Regulation of prostaglandin metabolism by calcitriol attenuates growth stimulation in prostate cancer cells. Cancer Research 65: 7917-7925.

145. Aparna R, Subhashini J, Roy KR, Reddy GS, Robinson M, Uskokovic MR, Venkateswara Reddy G, Reddanna P (2008) Selective inhibition of cyclooxygenase-2 (COX-2) by $1 \alpha, 25$ dihydroxy- 16-ene-23-yne-vitamin $\mathrm{D}_{3}$, a less calcemic vitamin D analog. J Cell Biochem 104: 1832-1842.

146. Sandalio LM, Rodríguez-Serrano M, Romero-Puertas MC, Del Río LA (2013) Role of Peroxisomes as a Source of Reactive Oxygen Species (ROS) Signaling Molecules. Subcell Biochem 69: 231-255.

147. Rahat MA, Hemmerlein B (2013) Macrophage-tumor cell interactions regulate the function of nitric oxide. Front Physiol 4: 144.

148. Javeed T, Mustafa G, Khan I, Khan MK (2011) Secondary defense antioxidant status of vitamin $\mathrm{C}$, vitamin $\mathrm{E}$ and GSH in malaria, caused by plasmodium Falciparum and plasmodium Vivax. Park J Pharm Sci 24: 103-107.

149. Narsaria N, Mohanty C, Das BK, Mishra SP, Prasad R (2012) Oxidative stress in children with severe malaria. J Trop Pediatr 58: 147-150.

150. Andrade BB, Reis-Filho A, Souza-Neto SM, Raffaele-Netto I, Camargo LM, Barral A, Barral-Netto M (2010) Plasma 
superoxide dismutase-1 as a surrogate marker of vivax malaria severity. PLoS Negl Trop Dis 4: e650.

151. Kavishe RA, Bousema T, Shekalaghe SA, Sauerwein RW, Mosha FW, van der Ven AJ, Russel FG, Koenderink JB (2009) Common genotypic polymorphisms in glutathione Stransferases in mild and severe falciparum malaria in Tanzanian children. Am J Trop Med Hyg 81: 363-365.

152. Cohen MS, Mesler DE, Snipes RG, Gray TK (1986) 1,25dihydroxyvitamin $\mathrm{D}_{3}$ activates secretion of hydrogen peroxide by human monocytes. J Immunol 136: 1049-1053.

153. Levy R, Malech HL (1991) Effect of 1,25-dihydroxyvitamin $\mathrm{D}_{3}$, lipopolysaccharide, or lipoteichoic acid on the expression of NADPH oxidase components in cultured human monocytes. J Immunol 147: 3066-3071.

154. Bao BY, Ting HJ, Hsu JW, Lee YF (2008) Protective role of 1 $\alpha, 25$-dihydroxyvitamin $\mathrm{D}_{3}$ against oxidative stress in nonmalignant human prostate epithelial cells. Int $\mathrm{J}$ Cancer 122: 2699-2706.

155. Somjen D, Katzburg S, Grafi-Cohen M, Knoll E, Sharon O, Posner GH (2011) Vitamin D metabolites and analogs induce lipoxygenase mRNA expression and as well as reactive oxygen species (ROS) production in human bone cell line. $\mathrm{J}$ Steroid Biochem Mol Biol 123: 85-89.

156. Sardar S, Chakraborty A, Chatterjee M (1996) Comparative effectiveness of vitamin $\mathrm{D}_{3}$ and dietary vitamin $\mathrm{E}$ on peroxidation of lipids and enzymes of the hepatic antioxidant system in Sprague-Dawley rats. Int J Vitam Nutr Res 66: 3945.

157. Garcion E, Sindji L, Leblondel G, Brachet P, Darcy F (1999) 1,25-dihydroxyvitamin $D_{3}$ regulates the synthesis of $\gamma$ glutamyl transpeptidase and glutathione levels in rat primary astrocytes. J Neurochem 73: 859-866.

158. Sugita K, Kabashima K, Yoshiki R, Ikenouchi-Sugita A, Tsutsui M, Nakamura J, Yanagihara N, Tokura Y (2010) Inducible nitric oxide synthase downmodulates contact hypersensitivity by suppressing dendritic cell migration and survival. J Invest Dermatol 130: 464-471.
159. Ahvazi BC, Jacobs P, Stevenson MM (1995) Role of macrophage-derived nitric oxide in suppression of lymphocyte proliferation during blood-stage malaria. J Leukoc Biol 58: 23-31.

160. Ghigo D, Todde R, Ginsburg H, Costamagna C, Gautret P, Bussolino F, Ulliers D, Giribaldi G, Deharo E, Gabrielli G, Pescarmona G, Bosia A (1995) Erythrocyte stages of Plasmodium falciparum exhibit a high nitric oxide synthase (NOS) activity and release an NOS-inducing soluble factor. J Exp Med 182: 677-688.

161. Dhangadamajhi G, Mohapatra BN, Kar SK, Ranjit M (2009) Genetic variation in neuronal nitric oxide synthase (nNOS) gene and susceptibility to cerebral malaria in Indian adults. Infect Genet Evol 9: 908-911.

162. Chang JM, Kuo MC, Kuo HT, Hwang SJ, Tsai JC, Chen HC, Lai YH (2004) 1- $\alpha, 25$-Dihydroxyvitamin $\mathrm{D}_{3}$ regulates inducible nitric oxide synthase messenger RNA expression and nitric oxide release in macrophage-like RAW264.7 cells. J Lab Clin Med 143: 14-22.

163. Garcion E, Nataf S, Berod A, Darcy F, Brachet P (1997) 1,25Dihydroxyvitamin $\mathrm{D}_{3}$ inhibits the expression of inducible nitric oxide synthase in rat central nervous system during experimental allergic encephalomyelitis. Brain Res Mol Brain Res 45: 255-267.

164. Equils O, Naiki Y, Shapiro AM, Michelsen K, Lu D, Adams J, Jordan S (2006) 1,25-Dihydroxyvitamin $\mathrm{D}_{3}$ inhibits lipopolysaccharide-induced immune activation in human endothelial cells. Clin Exp Immunol 143: 58-64.

\section{Corresponding author}

Khanh v.q. Lương

14971 Brookhurst St., Westminster, CA 92683, USA

Phone: 7148395898

Fax: 7148395989

Email:1ng2687765@aol.com

Conflict of interests: No conflict of interests is declared. 